\title{
PELATIHAN SELF INTEGRATED SENSORY TERAPHY (SIST) DAN PEMBUATAN VIDEO PEMBELAJARAN BAGI GURU SLBN Dr. RADJIMAN WEDYODININGRAT
}

\author{
Rischa Pramudia Trisnani1"), Wachidatul Linda Yuhanna ${ }^{2)}$ \\ 1)Program Studi Bimbingan dan Konseling, FKIP, Universitas PGRI Madiun, Madiun, Jawa Timur, Indonesia \\ 2) Program Studi Pendidikan Biologi, FKIP, Universitas PGRI Madiun, Madiun, Jawa Timur, Indonesia \\ Corresponding author : Wachidatul Linda Yuhanna \\ E-mail : pramudiarischa@unipma.ac.id; linda.yuhanna@unipma.ac.id
}

Diterima 29 Juli 2021, Direvisi 02 Agutus 2021, Disetujui 02 Agustus 2021

\begin{abstract}
ABSTRAK
Pandemi Covid-19 memberikan efek bagi pelaksanaan pembelajaran di SLBN Dr. Radjiman Wedyodiningrat. Guru SLB mengalami kesulitan dalam memberikan layanan pembelajaran dan terapi kepada ABK. Tim Program Kemitraan Masyarakat (PKM) Universitas PGRI Madiun bermaksud melakukan pelatihan Self Integrated Sensory Teraphy (SIST) pada guru dan memberi pelatihan pembuatan media pembelajaran visual berupa video. Sasaran dari PKM ini adalah guru sejumlah 11 orang. Tahapan yang dilakukan pada PKM ini adalah (1 Pembukaan, (2) penyampaian materi, (3) penyusunan ruang multimedia, (4) praktik pembuatan video pembelajaran, (5) evaluasi tingkat pemahaman guru dalam terapi SIST. Metode evaluasi yang dilakukan adalah dengan mengisi angket sejumlah 10 pertanyaan. Kegiatan ini dilakukan dengan diskusi dan tanya jawab secara interaktif. Guru banyak bertanya tentang penerapan SIST secara kontekstual yang dapat dilakukan secara mandiri.Terapi SIST adalah suatu jenis keterapian yang bertujuan untuk memperbaiki sistem regulasi dan modulasi dari berbagai input sensori dan memfasilitasi fungsi regulasi. Hasil dari PKM ini adalah adanya peningkatkan pemahaman guru terkait implementasi SIST pada ABK dengan kriteria sangat baik adalah $81 \%$ dan baik $19 \%$. Peningkatkan kompetensi guru untuk membuat media pembelajaran video untuk $A B K$ di SLBN Dr. Radjiman Wedyodiningrat dengan kriteria sangat baik $72 \%$, baik $19 \%$ dan cukup baik $9 \%$. Kegiatan selanjutnya adalah adanya pendampingan penggunaan IT dan implementasi terapi SIST dan video pembelajaran pada siswa ABK.
\end{abstract}

Kata kunci: guru; sensorik; SLB; terapi; terintegrasi.

\begin{abstract}
The Covid-19 pandemic has effects on the implementation of learning at SLBN Dr. Radjiman Wedyodiningrat. The SLB teachers difficulty in providing learning and therapy services to students with special needs. The PKM team of Universitas PGRI Madiun intends to conduct Self Integrated Sensory Therapy (SIST) training for the teachers and provide training in making visual learning media or videos. The target of this PKM is 11 teachers. The stages carried out in this PKM are (1) opening, (2) delivery of SIST material, (3) arrangement of multimedia room, 4) practice making learning videos, (5) evaluation of teacher's level of understanding in SIST therapy. The evaluation method used is by filling out a questionnaire of 10 questions. This activity is carried out with interactive discussion and question and answer. Teachers often ask about the application of SIST contextually that can be done independently. SIST therapy is a type of therapy that aims to improve the regulation and modulation system of various sensory inputs and facilitate regulatory functions. The result of this PKM is an increase in teacher understanding regarding the implementation of SIST with very good criteria being $81 \%$ and good $19 \%$. Improving teacher competence to make video learning media for ABK at SLBN Dr. Radjiman Wedyodiningrat with criteria very good $72 \%$, good $19 \%$ and quite good $9 \%$. The next activity is the assistance in the use of IT and the implementation of SIST therapy and learning videos for ABK students.
\end{abstract}

Keywords: teacher; sensory, SLB; therapy; integrated.

\section{PENDAHULUAN}

Pandemi

transformasi bagi

( Biasa (SLB). Efek dari pandemi yang mengharuskan pembelajaran dilakukan secara daring. Hal ini memberikan tantangan bagi guru, orang tua dan Anak Berkebutuhan Khusus
(ABK). ABK sangat memerlukan perhatian baik dari orang tua guru maupun lingkungan sekitar. ABK memerlukan penanganan khusus untuk melatih berbagai keterampilan secara intensif (Harahap \& Prastowo, 2021).

SLBN Dr. Radjiman Wedyodiningrat merupakan salah satu SLBN yang berada di 
Kecamatan Ngrambe, Kabupaten Ngawi Jawa Timur. Sekolah ini berdiri pada tanggal 16 Oktober 2017 dengan SK izin operasional No. 421.8/6265.24/101.4/2017. Jumlah siswa ABK di SLBN ini adalah 61 siswa dan 11 guru. Jenis layanan kebutuhan khusus di sekolah ini adalah tunanetra, tunarungu, tunagrahita, tuna daksa, tunawicara, autis dan berbagai jenis disabilitas lainnya. SLBN ini menerima siswa dari lima kecamatan di Kabupaten Ngawi. Kondisi ABK di SLBN Dr. Radjiman Wedyodiningrat berusia 712 tahun sebanyak 73\% dan usia 13-15 tahun sebanyak $27 \%$. Kondisi sosial ekonomi orang tua $A B K$ berasal dari keluarga menengah ke bawah.

Pembelajaran saat ini dilakukan secara daring melalui grup Whatapps dan seminggu dua kali dengan kunjungan ke rumah oleh guru. Guru sejumlah 11 orang belum mampu menjangkau kunjungan ke rumah secara optimal untuk ABK dari lima Kecamatan di Kabupaten Ngawi. Pembelajaran secara mandiri di rumah memerlukan dukungan dan peran serta orang tua dan keluarga (Fajrie \& Masfuah, 2018). Namun, tidak semua keluarga memahami layanan untuk anak ABK, terutama untuk mengasah kemampuan motorik, sensorik, konsentrasi dan terapi. Keterampilan life skils $A B K$ selama pembelajaran mandiri di rumah tidak begitu diperhatikan dan dilatihkan karena keterbatasan SDM guru dan keterbatasan pengetahuan dan perhatian dari orang tua.

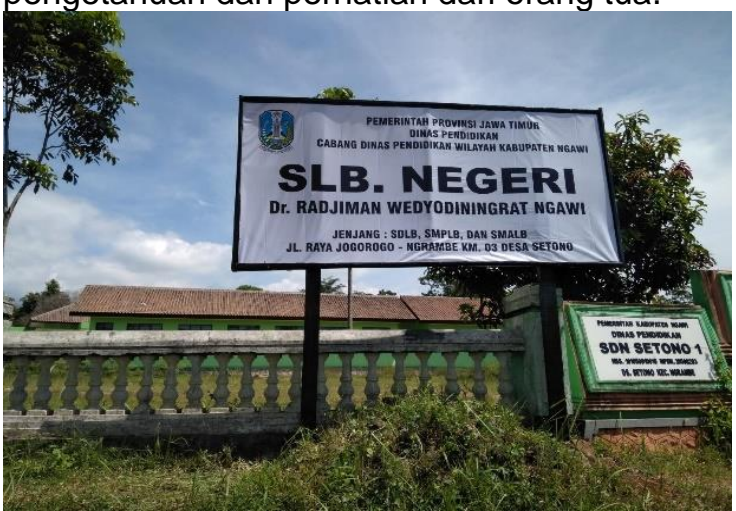

Gambar 1. SLBN Dr. Rdjiman Wedyodiningrat

Selama Pandemi Covid19 siswa ABK di SLBN Dr. Radjiman Wedyodiningrat mengalami kendala layanan kebutuhan khusus yang kurang optimal, karena guru tidak secara langsung berinteraksi dengan siswa $A B K$. Pembelajaran secara daring belum optimal, karena sebanyak $25 \%$ orang tua siswa ABK tidak mempunyai gawai untuk pembelajaran online dan melaporkan kegiatan ABK di rumah. Layanan yang diberikan orang tua tebatas kegiatan rutin sehari-hari, sehingga $A B K$ tidak diberikan layanan dan terapi yang terstruktur untuk keterampilan sensorik dan motoriknya. Sebanyak $86 \%$ ABK tidak memperoleh pembelajaran dan terapi selama pembelajaran mandiri di rumah di masa pandemi. ABK selama di rumah banyak menarik diri dari lingkungan sekitar, sehingga hal ini berpengaruh pada kondisi psikologi dan perkembangan sosioemosional anak.

Guru di SLBN Dr. Radjiman Wedyodiningrat juga mengalami kesulitan dalam memberikan layanan terapi kepada ABK. Sumber daya manusia sejumlah 11 guru tidak mencukupi untuk memberikan layanan kunjungan ke rumah secara kontinyu. Guru belum banyak mempunyai konten digital pembelajaran layanan khusus ABK secara daring (misalnya video pembelajaran, video terapi, dan layanan konseling). Guru belum bisa memantau perkembangan kompetensi siswa ABK secara detail karena sistem pembelajaran di masa Pandemi yang terbatas.

Guru juga kesulitan memotivasi dan mengajak orang tua untuk melakukan layanan ABK sesuai standar. Pembelajaran dan terapi yang semula dilatihkan di sekolah, ketika pandemi tidak dilatihkan lagi kerena keterbatasan waktu kunjungan ke rumah oleh guru. Kondisi orang tua ABK dari ekonomi menengah ke bawah juga berpengaruh pada tingkat kepedulian dan pendampingan layanan ABK secara mandiri di rumah. Orang tua banyak bergantung pada guru untuk memberikan terapi dan layanan.

Tim Program Kemitraan Masyarakat (PKM) Universitas PGRI Madiun bermaksud melakukan pelatihan Self Integrated Sensory Teraphy (SIST) pada guru dan memberi pelatihan pembuatan media pembelajaran visual. SIST menekankan stimulasi pada tiga indra utama, yaitu taktil, vestibular, dan proprioseptif. Ketiga sistem sensori ini memang tidak terlalu familiar dibandingkan indera penglihatan dan pendengaran, namun sistem ini sangat penting karena membantu interpretasi dan respon anak terhadap lingkungan dan keterampilan dalam menyelsaikan suatu pekerjaan (Kurnianingsih \& Alfiyanti, 2017). SIST dinilai relevan pada anakanak dengan kondisi retardasi mental ringan, disabilitas dan Autism Spectrum Disorder dalam mengoptimalkan pemrosesan sensori dan respon motorik. Implementasi SIST bisanya dikemas dalam praktik real untuk membuat sesuatu atau dengan bentuk permainan atau tantangan membuat suatu benda.

Terapi SIST banyak dilakukan pada anak disabilitas. Ada perbedaan kemampuan taktil anak sebelum dan setelah mendapatkan terapi sensori integrasi (Tanawali et al., 2018). Anak autis yang telah mengikuti terapi mengalami peningkatan kemampuan taktil. Terapi sensori 
integrasi dapat menyenangkan bagi anak-anak karena terapi menyerupai bermain (Arianti, 2018). Terapi SIST juga bisa didukung dengan terapi yang lain yaitu terapi okupasi (Setyabudi \& Hastutiningtyas, 2017). Terapi sensori terintegrasi dan terapi okupasi meningkatkan ketahanan tubuh, memperbaiki sikap tubuh, melepaskan energi anak yang berlebihan, dan meningkatkan interaksi sosial (Raffi et al., 2018). Terapi sensori terintegrasi dapat untuk mengatasi hambatan belajar anak tuna grahita. Terapi ini terbukti dapat digunakan untuk mengontrol emosi (Nisa et al., 2020).

Tujuan dari pelatihan ini adalah untuk 1) Meningkatkan pemahaman guru terkait implementasi SIST pada ABK. 2) Meningkatkan pemahaman guru untuk membuat media pembelajaran video untuk ABK di SLBN Dr. Radjiman Wedyodiningrat.

\section{METODE}

Kegiatan ini dilakukan di SLBN Dr. Radjiman Wedyodiningrat yang beralamat di Desa Setono Kecamatan Ngrambe Kabupaten Ngawi Jawa Timur pada bulan Juni 2021. Sasaran dari PKM ini adalah guru sejumlah 11 orang. Pelaksanaan pelatihan SIST dilakukan dengan mematuhi protokol kesehatan dengan mencuci tangan, menggunakan handsanitizer, memakai masker dan faceshield, dan menjaga jarak.

Tahapan yang dilakukan pada PKM ini adalah 1) Pembukaan, 2) Penyampaian materi SIST. 3) Penyusunan ruang multimedia. 4) Praktik pembuatan video pembelajaran. 5) Evaluasi tingkat pemahaman guru dalam terapi SIST.

Metode evaluasi yang dilakukan adalah dengan mengisi angket sejumlah 10 pertanyaan. Angket dianalisis secara deskriptif kuantitatif. Indikator ketercapaian program adalah adanya peningkatan pemahaman guru dengan kriteria baik dan sangat baik sejumlah $>70 \%$. Selain itu juga adanya video pembelajaran hasil karya dari guru SLBN Dr. Radjiman Wedyodiningrat.

\section{HASIL DAN PEMBAHASAN \\ Pembukaan}

Tahap pertama yang dilakukan tim PKM adalah melakukan pembukaan acara. Pada kegiatan ini disampaikan perkenalan, maksud, tujuan, kegiatan dan luaran yang akan dihasilkan. Acara ini juga disambut oleh kepala SLBN Dr. Radjiman Wedyodiningrat dan Pengawas SLBN Jawa Timur. Adanya dukungan dan motivasi kelembagaan sangat penting untuk penguatan kompetensi guru.

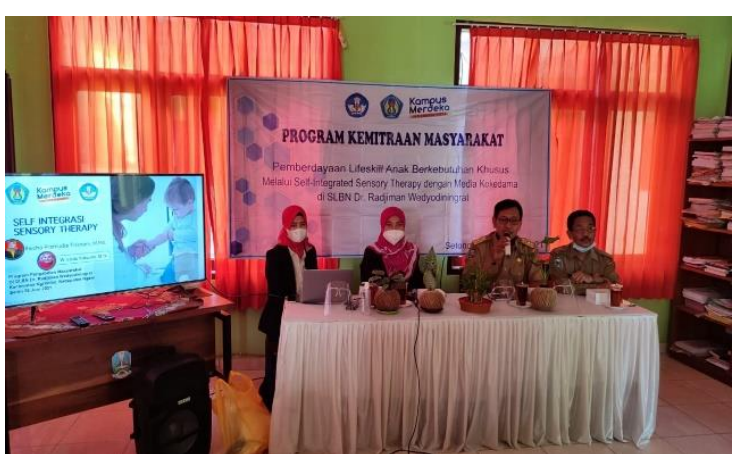

Gambar 2. Pembukaan dan sambutan

\section{Penyampaian materi SIST}

Tahapan kedua adalah penyampaian materi SIST oleh tim PKM. Materi yang disampaikan adalah tentang pentingnya Self Integrated Sensory Therapy (SIST) bagi anak berkebutuhan khusus kepada 11 guru SLBN Dr. Radjiman Wedyodiningrat. Pelatihan ini diharapkan guru dapat mengetahui manfaat dan bagaimana pelaksanaan terapi sensori integrasi bagi anak berkebutuhan khusus.

Kegiatan ini dilakukan dengan diskusi dan tanya jawab secara interaktif. Guru banyak bertanya tentang penerapan SIST secara kontekstual yang dapat dilakukan secara mandiri. Selain itu guru juga bertanya tentang pemaknaan dari SIST dalam kaitannya dengan disabilitas ABK. Tim PKM memberikan pengetahuan tentang contoh-contoh real ang dapat dilakukan. Selain itu tim juga menjelaskan makna SIST untuk mendukung perkembangan $\mathrm{ABK}$.

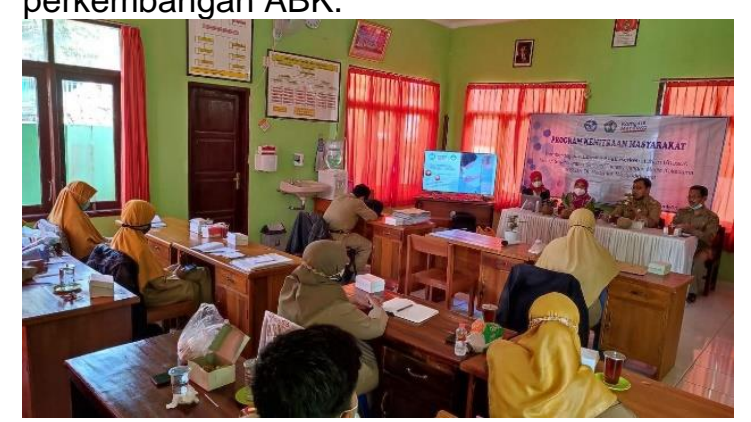

Gambar 3. Penyampaian materi SIST

Terapi SIST atau sensori terintegrasi adalah suatu jenis keterapian yang bertujuan untuk memperbaiki sistem regulasi dan modulasi dari berbagai input sensori, memfasilitasi fungsi regulasi (Solicha et al., 2021). Terapi ini memfasilitasi proses dari berbagai input sensori dan membantu perkembangan praktis dan keterampilan untuk memecahkan masalah (Novianti et al., 2020; Syaikh et al., 2019). Terapi itu sendiri merupakan suatu proses mengenal, mengubah, membedakan sensasi dari sistem sensori untuk menghasilkan suatu respon berupa "perilaku adaptif bertujuan" (Komariah, 2018) 
Materi kedua yang disampaikan adalah penyusunan materi ajar visual dengan media video. Guru diberikan pelatihan dan pengetahuan tentang setting ruang multimedia, produksi video, editing dan finishing media visual. Harapannya guru dapat membuat video pembelajaran bagi $A B K$ yang dapat disampaikan secara daring pada ABK dirumah. Kompetensi guru dalam TIK dan penyusunan media interaktif sangat penting untuk dilakukan (Permatasari et al., 2019)

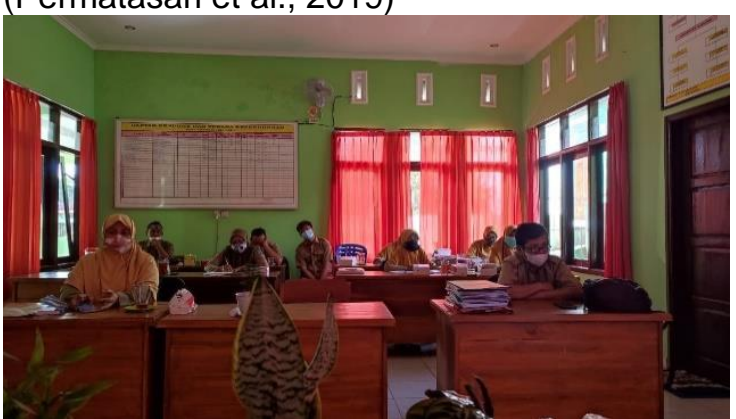

Gambar 4. Peserta pelatihan video pembelajaran

\section{Penyusunan ruang multimedia}

Tahapan ketiga adalah menyusun ruang multimedia yang dapat digunakan oleh guru untuk produksi video pembelajaran. Ruang multimedia dilengkapi dengan audio dan video yang mendukung penyampaian materi yang guru lakukan (Pangga et al., 2020). Ruangan ini diharapkan mampu mendorong guru untuk mengembangkan media pembelajaran.

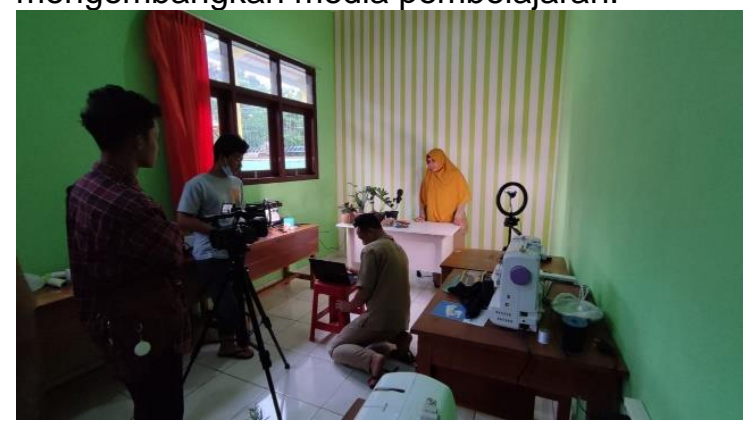

Gambar 5. Penyusunan ruang multimedia

Siswa ABK juga dapat menggunakan ruang ini untuk mendukung pembelajaran dan penguatan bakat minat. Ruangan multimedia saat ini sangat mendukung untuk proses pembelajaran secara daring. Ruangan ini dapat pula digunakan untuk unjuk karya siswa dan guru yang hasil akhirnya adalah video pembelajaran.

\section{Praktik pembuatan video pembelajaran}

Tahapan ini berisi praktik pembuatan video pembelajaran. Salah satu guru menjadi guru model untuk menyampaikan materi. Tim editing terdiri dari operator IT di SLBN Dr.
Radjiman Wedyodiningrat. Materi yang disampaikan adalah pembuatan kreasi kokedama dengan menggunakan bahasa isyarat. Pembuatan video ini berjalan lancar dan kondusif. Setelah mendapat materi secara teori dari tim PKM, guru mempraktekkan secara langsung.

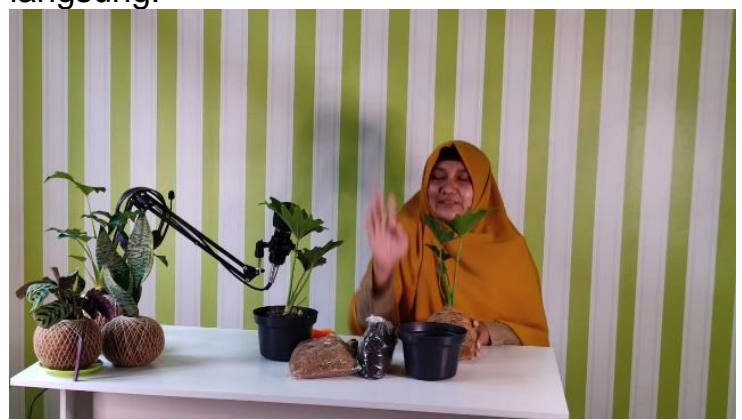

Gambar 6. Pembuatan video pembelajaran

Kendala pada proses ini adalah pencahayaan yang kurang, karena dilakukan pada sore hari. Namun secara substansi materi, editing dan proses produksi berjalan lancar. Guru semakin termotivasi dan tertarik dalam mengembangkan video interaktif. Video inilah yang akan disapaikan kepada grup orang tua, video ini juga akan ditayangkan secara daring pada pembelajaran di masa pandemi.

\section{Evaluasi tingkat pemahaman guru dalam terapi SIST}

Evaluasi diberikan dengan memberikan angket pada guru terkait isi materi SIST sebanyak 10 soal. Tingkat pemahaman guru disajikan dalam gambar 7. Gambar 7 menunjukkan bahwa secara klasikal tingkat pemahaman materi SIST dengan kriteria sangat baik adalah $81 \%$ dan baik $19 \%$. Hal ini menunjukkan bahwa peserta pelatihan ini paham terhadap materi yang diberikan. Pada aspek pembuatan video pembelajaran, persentase sangat baik sejumlah $72 \%$, baik $19 \%$ dan cukup baik $9 \%$. Guru masih kesulitan dalam proses editing vdeo. Upaya selanjutnya adalah tim PKM akan terus melakukan pendampingan, monitoring dan evaluasi selama 3 bulan ke depan. Peserta berkomitmen untuk terus melanjutkan kegiatan ini dan menjadi sekolah binaan Universitas PGRI Madiun. 


\section{Presentase Pemahaman Guru}

Video pembelajaran

Terapi SIST

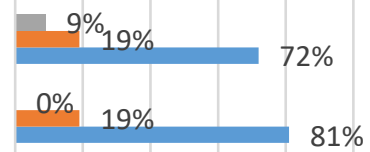

0\% $20 \% \quad 40 \% \quad 60 \% \quad 80 \% 100 \%$

n Cukup Baik Baik Sangat Baik

Gambar 7. Diagram tingkat pemahaman materi

Secara umum kegiatan ini dapat berjalan lancar dan kondusif. Guru mampu memahami materi SIST karena pada dasarnya guru sudah mempunyai basic skills untuk terapy ABK. Melalui terapi ini, guru dilatih untuk mengembangkan dan memodifikasi terapi ini menjadi kegiatan yang lebih menarik. Tim PKM juga menyampaikan materi dengan jelas disertai contoh-contoh real, sehingga memberikan pemahaman yang sederhana dan terpaut dalam long term memory. Pembuatan video pembelajaran, guru SLB sangat tertarik. Guru mempunyai kemampuan untuk tampil didepan kamera dan melakukan produksi video pembelajaran. Hal ini diyakini dapat menjadi solusi pembelajaran daring saat ini.

Kelebihan dari pelaksanaan program ini adalah (1) guru memperoleh kemampuan baru dalam mengembangan terapi SIST, (2) guru memperoleh pemahaman baru tentang pembuatan media pembelajaran berbasis multimedia (3) guru dan tim PKM dapat langsung berinteraksi dan berkolaborasi, sehingga membangun suasana yang kondusif, (4) guru sangat antusias dalam proses pengambilan video pembelajaran.

Namun, terdapat kelemahan dalam program PKM ini. Kelemahan tersebut adalah (1) adanya PPKM sehingga mengakibatkan reschedule kegiatan, (2) guru belum mempersiapkan materi yang akan dibuat video, (3) guru sulit untuk proses editing video pembelajaran. Kendala ini menjadi bahan kajian tim PKM untuk kegiatan pendampingan dan monitoring selanjutnya. Tim akan mengagendakan pelatihan editing video sebagai program lanjutan.

\section{SIMPULAN DAN SARAN}

Simpulan dari PKM ini adalah (1) adanya peningkatkan pemahaman guru terkait implementasi SIST pada ABK dengan kriteria sangat baik adalah $81 \%$ dan baik $19 \%$, dan 2) adanya peningkatkan kompetensi guru untuk membuat media pembelajaran video untuk $A B K$ di SLBN Dr. Radjiman Wedyodiningrat dengan kriteria sangat baik $72 \%$, baik $19 \%$, dan cukup baik $9 \%$.

Saran untuk kegiatan selanjutnya adalah adanya pendampingan penggunaan IT, editing video dan implementasi terapi SIST pada ABK secara langsung. Selain itu juga adanya penerapan video pembelajaran pada siswa ABK secara langsung.

\section{UCAPAN TERIMAKASIH}

Ucapan terimakasih penulis sampaikan kepada Kemdikbudristek yang telah membiayai kegiatan ini dari skim PKM tahun 2021.

\section{DAFTAR RUJUKAN}

Arianti,D. (2018). Pengaruh Terapi Bermain Terhadap Kemampuan Motorik Halus Anak Down Syndromedi Slb Ypplb Padang. Jik- Jurnal IImu Kesehatan, 2(1), 23-30. https://doi.org/10.33757/jik.v2i1.79

Fajrie, N., \& Masfuah, S. (2018). Model Media Pembelajaran Sains untuk Anak Berkebutuhan Khusus. Jurnal Bagimu Negeri, 2(1), 9-19. https://doi.org/10.26638/jbn.537.8651

Harahap, A. R., \& Prastowo, A. (2021). Kompetensi Guru Sekolah Dasar dalam Menyusun Perencanaan Pembelajaran di SLB Kasih Ibu Dolok Masihul Elementary School Teacher Competence in Developing Lesson Plans at Kasih Ibu Dolok Masihul Special School. Edu Society: Jurnal Pendidikan, IImu Sosial dan Pengabdian Kepada Masyarakat, 1(2), 191-199.

Komariah, F. (2018). Program Terapi Sensori Integrasi bagi Anak Tunagrahita di Yayasan Miftahul Qulub. Inklusi, 5(1), 45. https://doi.org/10.14421/ijds.050103

Kurnianingsih, R. P., \& Alfiyanti, D. (2017). Perkembangan Motorik Halus Pada Anak Autis Berdasarkan Kategori Anak Autis, Usia , Dan Jenis Kelamin (Studi Observasi Pada Siswa Sekolah Luar Biasa (SLB) Negeri Semarang ). Karya IImiah STIKES Telogorejo, 7, 1-10.Nisa, K., Dewi, N. K., Sriwarthini, N. P. N., Hidayati, V. R., \& Hasnawati, H. (2020). Pelatihan Terapi Sensori Integrasi Untuk Mengatasi Hambatan Belajar Anak Tuna Grahita di MI NW Tanak Beak. Jurnal Pendidikan Dan Pengabdian Masyarakat, 3(4).

Novianti, R., Satria, D., Author, C., \& Article, H. (2020). Pelatihan Terapi Sensori Integrasi Bagi Orang Tua dan Guru PAUD. 3, 181188.

Pangga, D., Ahzan, S., Gummah, S., \& Prayogi, S. (2020). Pelatihan Pembuatan Video Pembelajaran Untuk Guru Ma AlIstiqomah Nw Bedus. SELAPARANG 
Jurnal Pengabdian Masyarakat $\begin{array}{lrr}\text { Berkemajuan, } & 3(2), & 203 \\ \text { https://doi.org/10.31764/jpmb.v3i2.1512 }\end{array}$ https://doi.org/10.31764/jpmb.v3i2.1512 Permatasari, K., Degeng, I. N., \& Adi, E. (2019).
Pengembangan Suplemen Video Pembelajaran Adaptasi Makhluk Hidup untuk Siswa Tunarungu SLB-B YPLB Blitar. JKTP: Jurnal Kajian Teknologi Pendidikan, 2(4), 268-277. https://doi.org/10.17977/um038v2i42019p 268

Raffi, I., Ganis, I., \& Utami, S. (2018). Efektifitas Pemberian Terapi Okupasi Dalam Meningkatkan Kemandirian Makan Pada Anak Usia Sekolah Dengan Down Syndrome. Jurnal Keperawatan Sriwijaya, 5(2355), 146-154. https://lib.unnes.ac.id/23361/1/16014090 08.pdf

Setyabudi, I., \& Hastutiningtyas, W. R. (2017). Konsep Taman Pekarangan Sebagai Zona Terapi Dan Edukasi Bagi Anak Autis (Studi Kasus: Sekolah Luar Biasa (SIb) Sumber Dharma Malang). Jurnal Lanskap Indonesia, 2012, 52-62. https://doi.org/10.29244/jli.2017.9.1.52-62

Solicha, I., IImu Tarbiyah dan Keguruan, F., \& Sunan Kalijaga Yogyakarta, U. (2021). Terapi Sensori Integrasi Untuk Anak Downsyndrome Melalui Busy Book. Jurnal Pelita PAUD, 5(2), 162-170. https://doi.org/10.33222/pelitapaud.v5i2.1 210

Syaikh, I., Siddik, A., Belitung, B., (2019). Pengaruh Terapi Sensori Integrasi pada Anak Autis yang Mengalami Gangguan Sensori di Pusat Layanan Autis Provinsi Bangka Belitung. Mawa'izh: Jurnal Dakwah dan Pengembangan Sosial Kemasyarakatan, 10(1), 96-110.

Tanawali, N. H., Nur, H., \& Zainuddin, K. (2018). Peningkatan Kemampuan Taktil Anak Autis Melalui Terapi Sensori Integrasi. Jurnal Psikologi TALENTA, 3(2), 64.https://doi.org/10.26858/talenta.v3i2.6 528 